\begin{tabular}{|c|c|c|}
\hline \multirow{3}{*}{$\begin{array}{r}\text { Case Reports in } \\
\text { Gastroenterology }\end{array}$} & \multirow{2}{*}{\multicolumn{2}{|c|}{ Case Rep Gastroenterol 2014;8:297-303 }} \\
\hline & & \\
\hline & $\begin{array}{l}\text { DOI: 10.1159/000368394 } \\
\text { Publisned online: Uctober 7, } 2014\end{array}$ & $\begin{array}{l}\text { (c) } 2014 \text { S. Karger AG, Basel } \\
\text { 1662-0631/14/0083-0297\$39.50/0 } \\
\text { www.karger.com/crg }\end{array}$ \\
\hline & \multicolumn{2}{|c|}{$\begin{array}{l}\text { This is an Open Access article licensed under the terms of the Creative Commons } \\
\text { Attribution-NonCommercial } 3.0 \text { Unported license (CC BY-NC) (www.karger.com/OA } \\
\text { license), applicable to the online version of the article only. Distribution permitted for non } \\
\text { commercial purposes only. }\end{array}$} \\
\hline
\end{tabular}

\title{
Severe Refractory Coeliac Disease with Response Only to Parenteral Nutrition
}

\author{
Ka Ying Bonnie Ng Ravi Mehta Salma Mohamed Zameer Mohamed \\ Jayantha Arnold \\ Gastroenterology Department, Ealing Hospital, Southall, UK
}

\section{Key Words}

Refractory · Coeliac disease · Parenteral nutrition

\begin{abstract}
Refractory coeliac disease (RCD) is characterised by recurrent or persistent malabsorptive symptoms and villous atrophy, despite strict adherence to a gluten-free diet for at least 6 months and where other causes of malabsorption including malignancy have been excluded. There is limited evidence and guidance on the effective management of these patients. We describe a case of severe RCD in our hospital, with symptoms controlled effectively only by total parenteral nutrition (TPN). This 68-year-old woman initially presented to the clinic with persistent non-bloody diarrhoea and vomiting. A diagnosis of coeliac disease was confirmed with a positive tissue transglutaminase assay and histology. A strict gluten-free diet was ineffective and she represented 6 months later with $13 \mathrm{~kg}$ weight loss (16.7\%), ongoing abdominal pain and diarrhoea, with bowels opening 16 times a day. She was oedematous, had an albumin of $12 \mathrm{~g} / \mathrm{l}$ and required hospital admission. She was treated for pancreatic insufficiency and presumptively for small bowel bacterial overgrowth with no resolution of symptoms. We ruled out infectious causes and investigated for small bowel malignancy; all results were negative. Small bowel enteroscopy showed ulcerative jejunitis. She was given 5 days of TPN, following which her symptoms improved and albumin normalised. This was sustained with symptom resolution and weight gain seen at follow-up. TPN successfully and rapidly induced remission in this case. Thus, a short period of TPN should be considered as a potential component of management in patients with severe RCD.

(c) 2014 S. Karger AG, Basel
\end{abstract}

Dr. Ka Ying Bonnie $\mathrm{Ng}$

Chelsea and Westminster Hospital

369 Fulham Road

London SW10 9NH (UK)

E-Mail bonnie.ng@doctors.org.uk 
$\mathrm{Ng}$ et al.: Severe Refractory Coeliac Disease with Response Only to Parenteral Nutrition

\section{Introduction}

Coeliac disease (CD) is a common autoimmune condition affecting the small bowel; it is a gluten-sensitive enteropathy in genetically susceptible individuals [1]. Gluten is a constituent of wheat and gluten-like molecules are present in related foodstuffs including barley, rye and oats [2]. CD has a reported prevalence of up to $1 \%$ in western populations [1]. Advances in clinical awareness and serological testing have influenced its prevalence over the last decade $[1,3]$. It is reported 1.5 times more frequently in women compared with men and is also associated with a range of other autoimmune conditions [1, 3]. From a genetic perspective there is a strong association with the HLA-DQ2 and the HLA-DQ8 haplotype, which are expressed in over $90 \%$ of patients [1]. The pathogenesis of CD is thought to be related to an increase in intestinal permeability $[4,5]$ and the accumulation of gliadin in the lamina propria, which stimulates both the adaptive and innate immune responses. There is eventually enterocyte destruction and subsequent villous atrophy [6]. This manifests clinically in constitutional and malabsorptive symptoms, including diarrhoea, bloating and weight loss.

The diagnosis of $\mathrm{CD}$ relies on clinical presentation, detection of serum IgA autoantibodies and the demonstration of villous atrophy on duodenal biopsy (in accordance with Marsh's histological criteria) [7]. Most patients have a rapid recovery to normal health following a gluten-free diet (GFD), with improvement of symptoms seen within weeks to month [3]. In the majority, GFD induces both clinical and histological remission of the disease. The complications of this disease are related to malnutrition and an association with enterocyte-associated T cell lymphoma (EATL).

We present the clinical course of diagnosis and management in a case of refractory coeliac disease (RCD). This report highlights the particular therapeutic challenges faced by this phenomenon and the potential utility for parenteral nutrition in the management of such cases.

\section{Case History}

We present the case of a 68-year-old lady who developed persistent non-bloody diarrhoea and vomiting whilst travelling in India. She had a 10-day stay with her family, spending time in both urban and rural settings and drinking only bottled water and unpasteurised buffalo milk. She was treated for suspected gastroenteritis.

On return to the UK, her symptoms did not resolve and she was referred to the gastroenterology team at Ealing Hospital. Her initial clinical investigations revealed a positive tissue transglutaminase assay $(234 \mathrm{U} / \mathrm{ml}$, normal range $0-10 \mathrm{U} / \mathrm{ml})$ and normocytic anaemia (haemoglobin $10.9 \mathrm{~g} / \mathrm{l}$, mean corpuscular volume $87.1 \mathrm{fl}$ ). She had multiple stool cultures which were negative. Endoscopic biopsies from the second part of the duodenum showed shortened broad-based villi with an increased number of intraepithelial lymphocytes, consistent with a diagnosis of CD. She commenced a strict GFD, with a later addition of steroid therapy (budesonide). This did not control her symptoms, and when seen at follow-up (6 months after her initial presentation), she complained of worsening diarrhoea and steatorrhoea, with bowels opening up to 16 times a day. She also complained of colicky abdominal pain, significant weight loss (from 62 to $49 \mathrm{~kg}$ ) and was noted to be peripherally oedematous up to her knees.

Given the alarming rate of progression of her symptoms, she was admitted from the clinic to hospital. Clinically, we questioned whether this was progression of her CD or the 
$\mathrm{Ng}$ et al.: Severe Refractory Coeliac Disease with Response Only to Parenteral Nutrition

presentation of a second pathology. Her admission investigations were consistent with severe malnutrition and pancreatic exocrine insufficiency, with an albumin of $12 \mathrm{~g} / \mathrm{l}$ and reduced faecal elastase of $86 \mu \mathrm{g} / \mathrm{g}$. She was initially treated with a strict GFD, high-energy high-protein diet, Fresubin ${ }^{\circledR}$ energy drinks and Creon ${ }^{\circledR}$ supplementation, with no significant improvement.

While she was an inpatient, we proceeded to exclude other causes of malnutrition. Indeed, stool cultures were negative for bacteria, ova and cysts; tuberculosis was excluded with a negative QuantiFERON test; she was negative for HIV and was empirically treated for small bowel bacterial overgrowth with cyclical ciprofloxacin and metronidazole, with no effect. Her imaging included a normal computed tomography of the chest, abdomen and pelvis and a magnetic resonance imaging of the small bowel showing only small bowel diverticula. Upper gastrointestinal endoscopy showed chronic gastritis (negative for Helicobacter pylori) and colonoscopy was unremarkable, with no evidence of neoplasia in her biopsies. She underwent small bowel enteroscopy at a specialist unit (fig. 1) which showed ulcerative jejunitis, consistent with severe CD. Gene array studies of the biopsies obtained from D2 confirmed polyclonal $\mathrm{T}$ cell receptor arrangement, further reducing the likelihood of lymphoma. Thus overall, we were unable to find a second pathology explaining her intestinal failure, leaving RCD as her diagnosis of exclusion.

She was then given a short trial (5 days) of total parenteral nutrition (TPN) via a Hickman line. The TPN regimen was Kabiven 14 (day 1: $768 \mathrm{ml}$ at $32 \mathrm{ml} / \mathrm{h}$, day 2: 1,560 ml at $65 \mathrm{ml} / \mathrm{h}$, day $3: 1,920 \mathrm{ml}$ at $80 \mathrm{ml} / \mathrm{h}$, day $4: 1,920 \mathrm{ml}$ at $80 \mathrm{ml} / \mathrm{h}$, day $5: 1,920 \mathrm{ml}$ at $80 \mathrm{ml} / \mathrm{h}$ ). Table 1 details the constituents of each bag of Kabiven 14. While on TPN, her fluid balance, weight and blood sugar levels were closely monitored. In addition, she had daily monitoring of her haemoglobin, sodium, potassium, calcium, phosphate, magnesium, liver function tests, urea and creatinine. Following this period of TPN, her diarrhoea and steatorrhoea settled, her peripheral oedema improved and her albumin climbed to $34 \mathrm{~g} / \mathrm{l}$. She was transferred to a specialist intestinal failure unit, where she received just 2 further days of TPN before being safely discharged back to the community. A short period of TPN thus induced remission, characterised by a complete resolution of symptoms and biochemical improvement, which were sustained at follow-up.

\section{Discussion}

RCD is characterised by recurrent or persistent symptoms and villous atrophy despite strict adherence to a GFD for at least 6 months when other causes on non-responsive CD and malignancy have been excluded $[3,8,9]$. This is essentially a diagnosis of exclusion, made only after eliminating other causes of malabsorption, gluten contamination in diet and malignancy. RCD can be categorised into primary (persistent symptoms without initial response to diet) and secondary (relapse following initial response to diet) [7]. A further classification of RCD is recognised, type 1 and type 2. Type 1 RCD displays a predominantly normal intraepithelial lymphocyte population and type 2 RCD shows an aberrant population [10], whereby the intraepithelial lymphocytes demonstrate a loss of surface $\mathrm{T}$ cell receptor, CD3 or CD8 expression, and have a greater potential to progress and evolve into an aggressive EATL [11]. This explains the poor prognosis associated with type 2 (5-year survival between 44 and $58 \%$ ), in contrast to type 1 , which generally runs a benign course $[12,13]$. Immunohistochemistry for our patient showed the presence of CD3 and CD8, consistent with increased phenotypically normal intraepithelial lymphocytes in type 1 RCD (fig. 2). 
$\mathrm{Ng}$ et al.: Severe Refractory Coeliac Disease with Response Only to Parenteral Nutrition

Following the exclusion of other causes of malabsorption such as giardiasis, topical sprue, HIV and Whipple's disease, a diagnosis of primary RCD was confirmed in our patient. Currently there are no standardised treatment regimens for RCD due to the rarity of the condition. Clinicians are usually guided by the limited number of cases reported in the literature which have successfully responded to different managements [7]. There are a number of potential therapies already described in the literature, including the use of steroids and steroid-sparing agents such as azathioprine. In the majority of RCD type 1 cases, steroid use is effective in inducing clinical remission and mucosal recovery; however, use in RCD type 2 shows clinical response in $75 \%$, but does not induce mucosal recovery or prevent the progression to EATL.

Although majority of the literature focuses on immunosuppressive therapies for RCD treatment, nutritional support is an essential part of management which should not be overlooked. Hospitalisation is sometimes necessary to ensure dietary adherence and exclude gluten contamination. Symptomatic and histological improvement has been reported following hospitalisation for dietary monitoring [8]. Elemental and liquid diets can be used to ensure total gluten withdrawal [14]; however, malabsorption and protein-losing enteropathy can be so severe in some cases that patients may require intravenous nutritional support. Studies have shown that up to $60 \%$ of patients who were hospitalised for RCD required TPN due to severe weight loss, malnutrition, severe electrolyte abnormalities, complex nutritional deficiencies and/or steatorrhoea $[12,13,15]$. TPN has the ability to provide adequate nutrition and replacement of the necessary proteins whilst allowing time for intestinal mucosal recovery. All RCD patients would benefit from the involvement of an experienced dietician who can provide TPN regimes tailored to each patient's requirement. In our case, the patient showed improvement with TPN. Biochemically, her albumin levels increased from 12 to $34 \mathrm{~g} / \mathrm{l}$ and her haemoglobin improved from 6.7 to $12 \mathrm{~g} / \mathrm{dl}$ at follow-up 6 months later. Clinically, her diarrhoea slowly subsided within 1 week of starting TPN, and her weight increased from $39 \mathrm{~kg}$ on admission to $43 \mathrm{~kg}$ at follow-up.

We have described a case of severe RCD where symptoms persisted despite a strict GFD, treatment with steroids, antibiotics for small bowel bacterial overgrowth and pancreatic supplementation for pancreatic insufficiency. There is limited evidence and guidance on the most effective treatment options for RCD patients. Currently, only a strict GFD has been shown to be effective. However, our case illustrates the importance of the consideration of TPN in patients presenting with RCD; a short period of TPN in our patient induced remission of $\mathrm{CD}$, enabling successful recovery, weight gain and total control of symptoms. This was sustained at follow-up.

\section{Acknowledgements}

We would like to thank Dr. A. Pal and Dr. S. Shariq for their help in revising the manuscript, Dr. J. Hoare for providing us with the enteroscopy images for inclusion in this case report, and Dr. F. Kubba for providing the immunohistochemistry images.

\section{Disclosure Statement}

We declare no support from or financial relationships with any organizations that might have an interest in the submitted work. We declare no financial, personal or professional 
$\mathrm{Ng}$ et al.: Severe Refractory Coeliac Disease with Response Only to Parenteral Nutrition

competing interests related to the work. No ethical approval was required. The subject gave informed consent for publication. We maintained patient anonymity throughout the report.

\section{References}

1 Green PH, Cellier C: Celiac disease. N Engl J Med 2007;357:1731-1743.

- Husby S, Koletzko S, Korponay-Szabó IR, Mearin ML, Phillips A, Shamir R, Troncone R, Giersiepen K, Branski D, Catassi C, Lelgeman M, Mäki M, Ribes-Koninckx C, Ventura A, Zimmer KP; ESPGHAN Working Group on Coeliac Disease Diagnosis; ESPGHAN Gastroenterology Committee; European Society for Pediatric Gastroenterology, Hepatology, and Nutrition: European Society for Pediatric Gastroenterology, Hepatology, and Nutrition guidelines for the diagnosis of coeliac disease. J Pediatr Gastroenterol Nutr 2012;54:136-160.

-3 Ciclitira PJ, King AL, Fraser JS: AGA technical review on celiac sprue. American Gastroenterological Association. Gastroenterology 2001;120:1526-1540.

4 Clemente MG, De Virgiliis S, Kang JS, Macatagney R, Musu MP, Di Pierro MR, Drago S, Congia M, Fasano A: Early effects of gliadin on enterocyte intracellular signalling involved in intestinal barrier function. Gut 2003;52:218-223.

5 Fasano A, Not T, Wang W, Uzzau S, Berti I, Tommasini A, Goldblum SE: Zonulin, a newly discovered modulator of intestinal permeability, and its expression in coeliac disease. Lancet 2000;355:1518-1519.

-6 Barker JM, Liu E: Celiac disease: pathophysiology, clinical manifestations, and associated autoimmune conditions. Adv Pediatr 2008;55:349-365.

7 Nijeboer P, van Wanrooij RL, Tack GJ, Mulder CJ, Bouma G: Update on the diagnosis and management of refractory coeliac disease. Gastroenterol Res Pract 2013;2013:518483.

-8 Cellier C, Cerf-Bensussan N: Treatment of clonal refractory celiac disease or cryptic intraepithelial lymphoma: a long road from bench to bedside. Clin Gastroenterol Hepatol 2006;4:1320-1321.

$\$ 9$ Wahab PJ, Meijer JW, Goerres MS, Mulder CJ: Coeliac disease: changing views on gluten-sensitive enteropathy. Scand J Gastroenterol Suppl 2002;236:60-65.

10 Daum S, Cellier C, Mulder CJ: Refractory coeliac disease. Best Pract Res Clin Gastroenterol 2005;19:413-424.

11 Verbeek WH, Goerres MS, von Blomberg BM, Oudejans JJ, Scholten PE, Hadithi M, Al-Toma A, Schreurs MW, Mulder CJ: Flow cytometric determination of aberrant intra-epithelial lymphocytes predicts T-cell lymphoma development more accurately than T-cell clonality analysis in refractory celiac disease. Clin Immunol 2008;126:48-56.

12 Malamut G, Afchain P, Verkarre V, Lecomte T, Amiot A, Damotte D, Bouhnik Y, Colombel JF, Delchier JC, Allez M, Cosnes J, Lavergne-Slove A, Meresse B, Trinquart L, Macintyre E, Radford-Weiss I, Hermine O, Brousse N, Cerf-Bensussan N, Cellier C: Presentation and long-term follow-up of refractory celiac disease: comparison of type I with type II. Gastroenterology 2009;136:81-90.

13 Rubio-Tapia A, Kelly DG, Lahr BD, Dogan A, Wu TT, Murray JA: Clinical staging and survival in refractory celiac disease: a single center experience. Gastroenterology 2009;136:99-107; quiz 352-353.

14 Mandal A, Mayberry J: Elemental diet in the treatment of refractory coeliac disease. Eur J Gastroenterol Hepatol 2001;13:79-80.

15 Mauriño E, Niveloni S, Cherñavsky AC, Sugai E, Vázquez H, Pedreira S, Periolo N, Mazure R, Smecuol E, Moreno ML, Litwin N, Nachman F, Kogan Z, Bai JC: Clinical characteristics and long-term outcome of patients with refractory sprue diagnosed at a single institution. Acta Gastroenterol Latinoam 2006;36:10-22. 


\section{Case Reports in
Gastroenterology}

\begin{tabular}{l|l}
\hline Case Rep Gastroenterol 2014;8:297-303 \\
\hline DOI: 10.1159/000368394 & $\begin{array}{l}\text { @ 2014 S. Karger AG, Basel } \\
\text { www.karger.com/crg }\end{array}$ \\
\hline
\end{tabular}

$\mathrm{Ng}$ et al:: Severe Refractory Coeliac Disease with Response Only to Parenteral Nutrition

Table 1. Constituents of Kabiven 14 per bag

$\begin{array}{ll}\text { Nitrogen, g } & 13.5 \\ \text { Glucose, g/kcal } & 250 / 1,000 \\ \text { Lipid, g/kcal } & 100 / 1,000 \\ \text { Total non-protein energy, kcal } & 2,000 \\ \text { Sodium, mmol } & 80 \\ \text { Potassium, mmol } & 60 \\ \text { Calcium, mmol } & 5 \\ \text { Magnesium, mmol } & 10 \\ \text { Phosphate, mmol } & 25 \\ \text { Osmolarity, mOsm/l } & 1,230\end{array}$

Each bag contains a total volume of 2,566 ml.

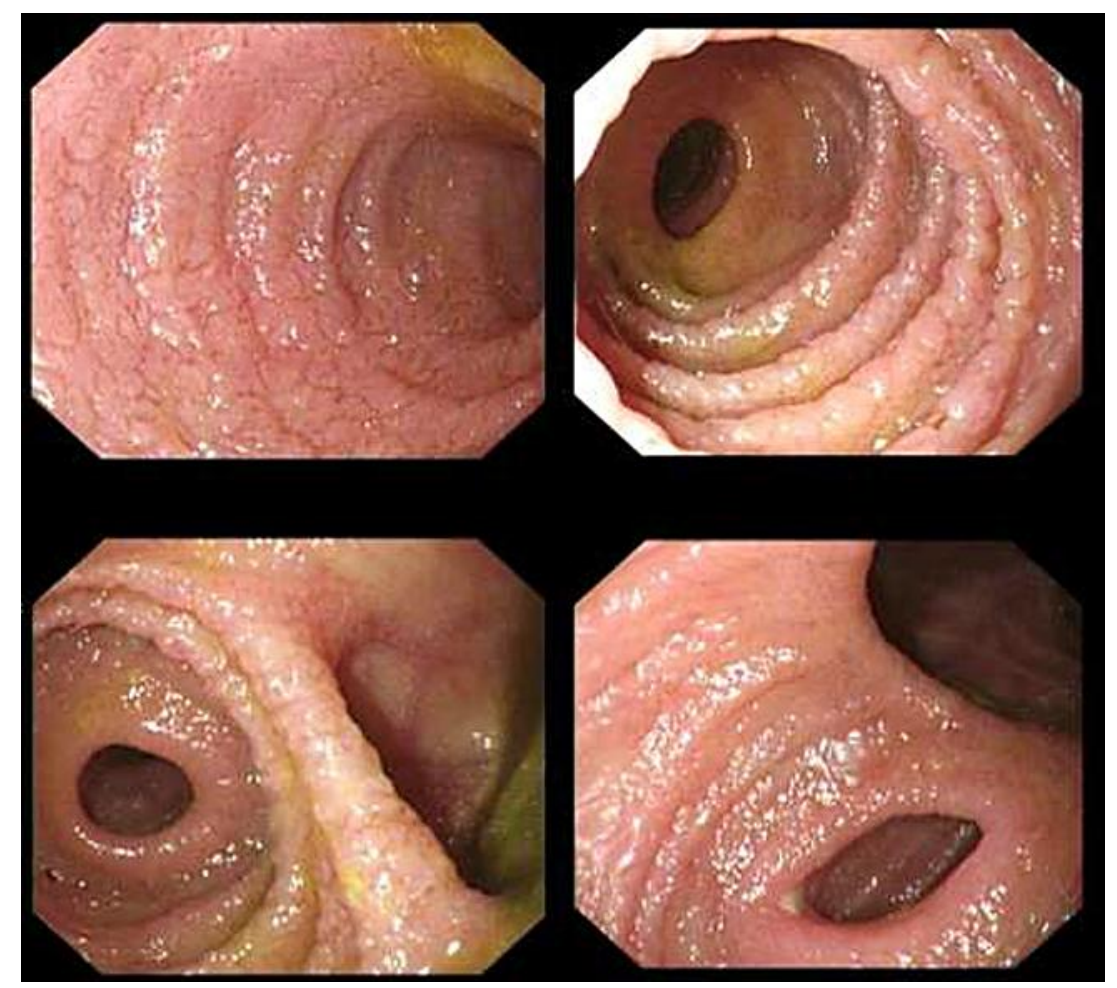

Fig. 1. Small bowel enteroscopy images showing a grossly oedematous jejunum with flat mucosal harbouring, scalloping effect and diverticulum. 


\begin{tabular}{rll} 
Case Reports in & \multicolumn{2}{l}{ Case Rep Gastroenterol 2014;8:297-303 } \\
\cline { 2 - 3 } Gastroenterology & DOI: 10.1159/000368394 & $\begin{array}{l}\text { ○ 2014 S. Karger AG, Basel } \\
\text { www.karger.com/crg }\end{array}$ \\
\cline { 2 - 3 }
\end{tabular}

$\mathrm{Ng}$ et al.: Severe Refractory Coeliac Disease with Response Only to Parenteral Nutrition

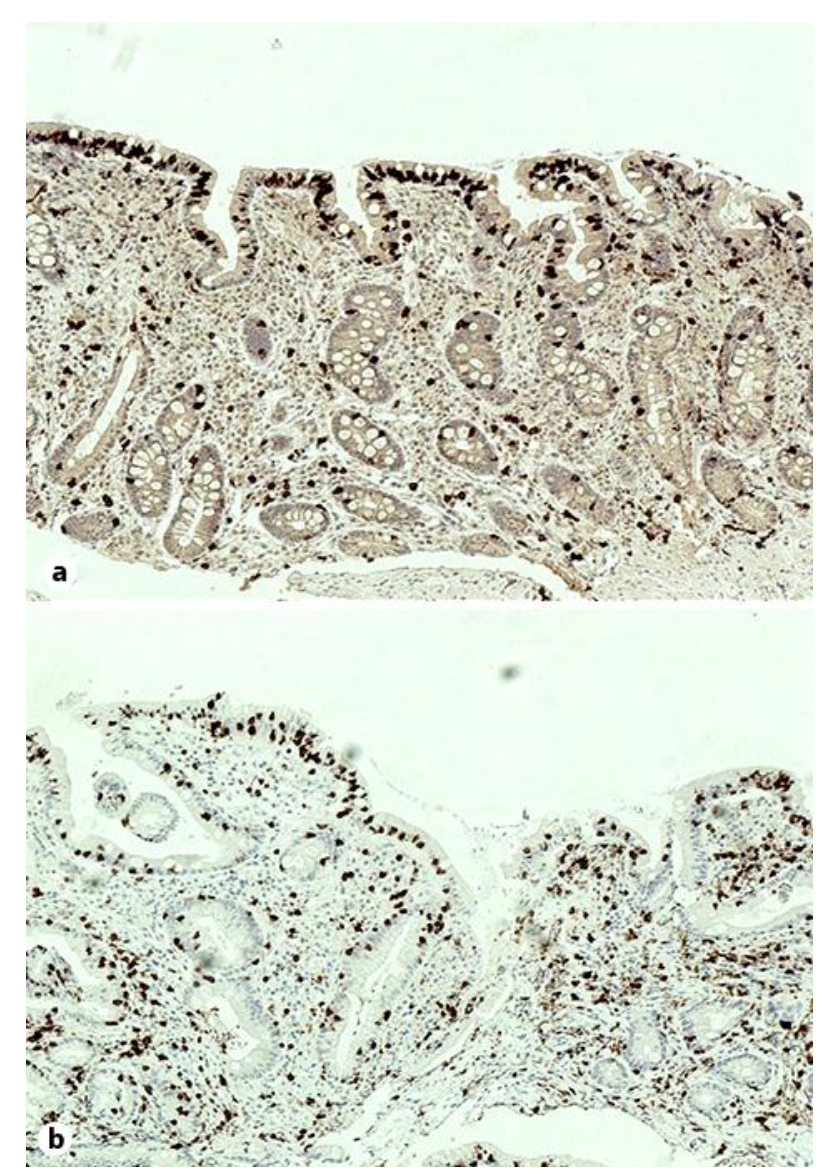

Fig. 2. Immunohistochemistry images from the small bowel showing presence of CD3 (a) and CD8 (b), consistent with increased phenotypically normal intraepithelial lymphocytes in type 1 RCD. 